\title{
KANDUNGAN NITRAT DAN FOSFAT DALAM AIR PORI SEDIMEN DI SUNGAI DAN MUARA SUNGAI WEDUNG DEMAK
}

\author{
Mutiara Arizuna, Djoko Suprapto ${ }^{I}$, Max R. Muskananfola \\ Program Studi Manajemen Sumberdaya Perairan, Jurusan Perikanan \\ Fakultas Perikanan dan Ilmu Kelautan, Universitas Diponegoro
}

\begin{abstract}
ABSTRAK
Secara alamiah konsentrasi zat hara dalam perairan bervariasi untuk masing-masing bentuk senyawanya, termasuk nitrat dan fosfat. Namun dalam kondisi tertentu dapat terjadi keadaan di luar batas yang dinyatakan aman untuk kategori perairan tertentu. Peranan nitrat dan fosfat yang terkandung didalam sedimen yang ada di sungai atau muara adalah sebagai unsur penting bagi pertumbuhan dan kelangsungan hidup organisme didalamnya. Penelitian ini bertujuan untuk mengetahui perbedaan dan faktor-faktor yang mempengaruhi kandungan nitrat dan fosfat dalam air pori sedimen antara sungai dan muara Sungai Wedung Demak. Penelitian dilaksanakan pada tanggal 15 - 29 Juni 2013 di Perairan Sungai Wedung Demak. Pengambilan sampel dilaksanakan sekali setiap 1 minggu.

Metode penelitian ini menggunakan analisis deskriptif. Metode pengambilan air pori sedimen dan kualitas air dilakukan pada pagi hari sekitar pukul 07.00 WIB dan siang hari sekitar pukul 12.30 WIB. Titik sampling terdiri dari dua ekosistem yaitu sungai dan muara. Setiap ekosistem terdapat tiga titik sampling. Analisa kandungan nitrat dan fosfat menggunakan metode Hach Programme. Pengukuran kualitas air meliputi salinitas, suhu, oksigen terlarut, $\mathrm{pH}$, dan kecerahan. Analisa data menggunakan uji IndependentSample T Test. Hasil penelitian menunjukkan bahwa terdapat perbedaan kandungan unsur hara pada air pori sedimen di sungai maupun muara Sungai Wedung Demak. Oksigen terlarut, suhu, $\mathrm{pH}$, dan kecerahan adalah faktor-faktor lingkungan yang mempengaruhi kandungan nitrat dan fosfat pada air pori sedimen.
\end{abstract}

Kata kunci : Nitrat, Fosfat, Air Pori Sedimen, Sungai, Muara

\section{ABSTRACT}

Naturally nutrient concentration of the substance in the water varies for each of the forms of its compounds, including nitrates and phosphates in this case. However under certain conditions, it can occur outside the boundaries of a state that was declared safe for certain waters category. The role of nitrates and phosphates contained in the sediments in the river or estuary is an important element for the growth and survival of organism. The research is aimed to know the difference and factors that affect the content of nitrate and phosphate in pore water sediment between the river and estuary of the Wedung River Demak. This research was conducted on 15 - 29 June 2013. Sample tobe collected once every week.

This research method using descriptive analysis. Pore water Sediment and water quality were taken in the morning around $7.00 \mathrm{am}$ and daylight at $12.30 \mathrm{pm}$. The points of sampling consist of two ecosystem that is a river and estuary. There are three point of sampling at ecosystem. Analysis of nitrate and phosphate content used methods Hach Programme. Measurement of water quality cover salinity, temperature, oxygen dissolved, $\mathrm{pH}$, and transparancy. Data analysis using Independent Sample T-Test. The result showed that there are difference in nutrient content on pore water sediment in rivers and estuary of Wedung River Demak. Salinity, temperature, dissolved oxygen, $\mathrm{pH}$, and transparancy are environmental factors affect content of nitrate and phosphate in the pore water sediment.

Keywords: Nitrate, Phosphate, Pore Water Sediment , River, Estuary

*) Penulis Penanggung Jawab 


\section{Pendahuluan}

Sungai merupakan perairan yang memilik peran penting bagi makhluk hidup. Keberdaan ekosistem sungai dapat memberikan manfaat bagi makhluk hidup, baik yang hidup didalam sungai maupun yang ada disekitarnya. Kegiatan manusia sebagai bentuk kegiatan pembangunan akan berdampak pada perairan sungai. Adanya kegiatan manusia dan industri memanfaatkan sungai sebagai tempat untuk membuang limbah. Hal tersebut akan berdampak pada penurunan kualitas air, yaitu dengan adanya perubahan kondisi fisika, kimia dan biologi (Sastrawijaya, 1991).

Sungai akan memperoleh masukan bahan maupun energi yang berasal dari wilayah sepanjang aliran sungai ataupun segala aktivitas manusia yang berkaitan dengan produksi limbah dan kemudian dialirkan melalui badan-badan sungai. Pembangunan industri di daerah permukiman sepanjang aliran sungai memberikan masukan bahan-bahan pencemar bagi perairan sungai yang pada akhirnya akan dialirkan ke muara (Santoso, 2007).

Muara didefinisikan sebagai wilayah pesisir semi tertutup yang mendapatkan aliran air tawar dari daratan serta mempunyai hubungan bebas dengan laut terbuka. Wilayah ini mempunyai karakteristik yang berbeda dengan laut maupun perairan air tawar. Salinitas air di wilayah ini sangat bervariasi karena adanya pengaruh air laut dan air tawar tersebut. Bercampurnya kedua jenis air tersebut dipengaruhi pasang surut yang berlangsung secara berkala yang juga membawa zat hara (Harsono, 2002).

Fosfat dan nitrat merupakan salah satu zat hara yang dibutuhkan dan mempunyai pengaruh terhadap pertumbuhan dan perkembangan hidup organisme di perairan. Fitoplankton merupakan salah satu parameter biologi yang erat hubungannya dengan fosfat dan nitrat. Tinggi rendahnya kelimpahan fitoplankton disuatu perairan tergantung kepada kandungan zat hara diperairan tersebut antara lain zathara fosfat dan nitrat, sama halnya dengan zat hara lainnya, kandungan fosfat dan nitrat di suatu perairan, secara alami tersedia sesuai dengan kebutuhan organisme yang hidup di perairan tersebut (Nybakken, 1988).

Kandungan fosfat dan nitrat di suatu daerah estuari selain berasal dari perairan itu sendiri juga tergantung kepada keadaan sekelilingnya,seperti sumbangan dari daratan melalui sungai ke perairan tersebut, juga tergantung kepada hutan mangrove yang serasahnya membusuk, karena adanya bakteri berurai menjadi zat hara fosfat dan nitrat. Zat hara seperti fosfat dan nitrat merupakan zat yang diperlukan dan mempunyai pengaruh terhadap proses pertumbuhan dan perkembangan hidup organisme di perairan

Secara alamiah konsentrasi zat hara dalam perairan bervariasi untuk masing-masing bentuk senyawanya, termasuk nitrat dan fosfat dalam hal ini. Namun dalam kondisi tertentu dapat terjadi keadaan di luar batas yang dinyatakan aman untuk kategori perairan tertentu. Kondisi yang dimaksud antara lain terjadinya pembuangan limbah yang melewati batas konsentrasi yang telah ditentukan oleh instansi berwenang yang menyebabkan terjadi penurunan kualitas perairan yang berdampak negatif terhadap biota yang hidup di perairan tersebut (Santoso, 2007).

Peranan nitrat dan fosfat yang terkandung didalam sedimen yang ada di sungai atau muara sungai adalah sebagai unsur yang penting bagi pertumbuhan dan kelangsungan hidup bagi organisme di dalamnya. Organisme tersebut berperan sebagai mata rantai dari rantai makanan yang mendukung produktivitas perairan. Pengkayaan zat hara di lingkungan perairan memiliki dampak positif, namun pada tingkatan tertentu juga dapat menimbulkan dampak negatif. Dampak positifnya adalah terjadi peningkatan produksi fitoplankton dan total produksi sedangkan dampak negatifnya adalah terjadinya penurunan kandungan oksigen di perairan, penurunan biodiversitas dan terkadang memperbesar potensi muncul dan berkembangnya jenis fitoplankton berbahaya yang lebih umum dikenal dengan istilah Harmful Algal Blooms atau HABs (Risamasu dan Prayitno, 2011). Pemeriksaan kandungan nitrat dan fosfat atau sering disebut sebagai zat hara perlu dilakukan karena parameter tersebut merupakan parameter tingkat kesuburan suatu perairan (Wibisono, 2005).

Tujuan penelitian ini adalah untuk mengetahui perbedaan kandungan nitrat dan fosfat dan untuk mengetahui faktor-faktor yang berperan pada kandungan nitrat dan fosfat di air pori sedimen yang terletak di sungai dan muara Sungai Wedung Demak. Penelitian ini dilaksanakan pada tanggal 15 - 29 Juni 2013 di Sungai Wedung Demak. Analisis nitrat dan fosfat dilakukan di Laboraturium Ilmu-Ilmu Perairan, Fakultas Perikanan dan Ilmu Kelautan, Universitas Diponegoro.

\section{Materi dan Metode Penelitian}

\section{A. Materi Penelitian}

Materi yang digunakan dalam penelitian ini di muara Sungai Sayung Demak terdiri dari variabel utama dan variabel pendukung. Variabel utama terdiri dari jenis - jenis fitoplankton, klorofil-a, bahan organik, nitrat, dan fosfat dan variabel penunjang (variabel fisika dan variabel kimia). Alat-alat yang digunakan dalam penelitian ini adalah refraktrometer untuk mengukur salinitas, termometer air raksa untuk mengukur suhu, seschi disc untuk mengukur kecerahan, $\mathrm{pH}$ paper untuk mengukur $\mathrm{pH}$, GPS untuk mengetahui koordinat titik sampling, DO meter untuk mengukur oksigen terlarut, Flowmeter untuk mengukur arus, Kooring untuk mengambil sedimen pada kedalaman tertentu, pore water pressure untuk mengeluarkan air dari sedimen, Penyedot air kolom untuk mengambil air pada kedalaman tertentu, pralon 
untuk menyimpan sedimen, kain parasut untuk membungkus sedimen pada saat dipres, kertas saring untuk menyaring air sedimen, spektrofotometer untuk mengukur kandungan nitrat dan fosfat, dan kamera digital untuk dokumentasi. Bahan yang digunakan adalah sedimen, reagen Nitrat Ver5 Nitrate dan fosfat Phos Ver3.

\section{B. Metode Penelitian}

Metode penelitian ini menggunakan analisis deskriptif, dengan maksud membuat deskripsi mengenai situasi - situasi atau kejadian - kejadian yang bertujuan membuat deskripsi secara sistematis, faktual, dan akurat mengenai fakta fakta. Penelitian ini bersifat survey dalam pengmpulan sumber data, yaitu pengamatan atau penyelidikan secara kritis terhadap persoalan tertentu yang dilakukan terhadap sekumpulan objek dengan asumsi bahwa objek yang diteliti telah mewakili populasi yang telah diamati (Hadi, 1993).

\section{Lokasi sampling}

Sungai yang dimaksud dalam metode penelitian ini adalah perairan yang tawar atau bersalinitas $0 \%$. Muara sungai yang dimaksud dalam penelitian ini adalah perairan yang berbatasan dengan laut tetapi masih dipengaruhi juga oleh sungai.

\section{Penentuan titik sampling}

Lokasi pengambilan sampel pada penelitian ini dilakukan di sungai dan muara Sungai Wedung. Pengambilan sampel dilakukan pada 6 titik di tiap-tiap lokasi dengan sejajar lebar sungai. Penelitian ini dilakukan selama 28 hari dengan interval waktu 1 minggu sekali. Stasiun yang diukur adalah sebagai berikut:

1. Titik 1

Pengambilan sampel zat hara berasal tepi sungai sebelah kanan (menuju arah laut) biasanya ditumbuhi tanaman sedangkan tepi muara kanan ditumbuhi oleh mangrove yang sudah besar.

2. Titik 2

Pengambilan sampel zat hara berasal dari tengah perairan antara tepi kanan dan kiri dengan jarak $25 \mathrm{~m}$.

3. Titik 3

Pengambilan sampel zat hara berasal dari tepi sungai atau muara sebelah kiri ditumbuhi oleh mangrove yang masih kecil. Sama seperti titik sampling yang kedua hanya berjarak 25 meter dari titik sampling pertama dan keempat.



Keterangan:

= Titik Sampling

S1 = Sungai titik satu

S2 = Sungai titik dua

M1 = Muara titik satu

S3 = Sungai titik tiga

$\mathrm{M} 2=$ Muara titik dua

M3 = Muara titik tiga

\section{Metode sampling}

a. Metode pengambilan air pori sedimen

Metode ini dilakukan pada pagi hari sekitar pukul 07.00 WIB dan siang hari sekitar pukul 12.30 WIB serta dilakukan tiga kali pengulangan. Tahap-tahap pengambilan sampel air pori sedimen:

1. Sedimen diambil dengan menggunakan koor yang dimasukkan sedalam $20 \mathrm{~cm}$ dari permukaan.

2. Kemudian sampel dimasukkan kedalam pralon yang didalamnya sudah diberi plastik untuk mencegah kebocoran. Lalu pralon disimpan kedalam ice box.

3. Sampel yang akan dipres dikeluarkan terlebih dahulu dari pralon lalu dibungkus dengan kain parasut kemudian baru dimasukkan ke Pore Water Pressure.

4. Dengan menggunakan dongkrak Pore Water Pressure ditekan keatas lalu menggunakan tekanan itu akan dihasilkan air pori sedimen.

5. Air pori sedimen ditampung sesuai kebutuhan kemudian disaring terlebih dahulu menggunakan kertas saring lalu dimasukkan kedalam botol sampel.

\section{b. Analisa nitrat $\left(\mathrm{NO}_{3}\right)$}

Analisa kandungan nitrat dalam air menggunakan metode Hach Programme. Metode pengukuran nitrat dilakukan dengan cara berikut : 
1. menyiapkan sampel air pori sedimen sebanyak $10 \mathrm{ml}$;

2. menyiapkan spektrofotometer Hach pada $\mathbf{3 5 5} \mathbf{~ N}$, Nitrate HR kemudian pilih start;

3. Menyiapkan 6 botol sampel; 3 botol ditandai sebagai blanko dan 3 botol lain sebagai sampel (gunakan kertas label untuk pelabelan pada tutup botol sampel); (B1, B2, dan B3 sebagai blanko dan 1,2 dan 3 sebagai sampel);

4. Mengisi botol B1 B2 dan B3 dengan $10 \mathrm{ml}$ air sampel sebagai blanko; botol 12 dan 3 sebagai sampel yang akan ditambah reagen;

5. Menambahkan reagen Nitrat Ver5 Nitrate ke dalam botol 123

6. Mengatur waktu pada spektro. Mengocok sampel selama satu menit, sampel dikocok dengan kuat sampai waktu berbunyi;

7. Ketika waktu berbunyi, pilih ikon waktu dan tekan $\mathbf{O K}$;

8. Mendiamkan sampel selama 5 menit (atur waktu pada Hach spektro) sambil menuggu keenam botol sampel sebaiknya dibersihkan dengan tisu sehingga tidak ada sidik jari yang menempel;

9. Setelah 5 menit, menyiapkan botol B1 B2 B3 lalu masukkan B1 kedalam spektrofotometer;

10. Kemudian tekan ikon Zero, layar akan menunjukkan $\mathbf{0 , 0} \mathbf{~ m g} / \mathbf{L ~ N O}_{3}{ }^{-} \mathbf{N}$;

11. Selanjutnya memasukkan botol 1 kedalam spektro dan lakukan pembacaan; Hasil akan muncul dalam $\mathbf{m g} / \mathbf{L}$;

12. Lakukan hal yang sama pada sampel berikutnya (B2 lalu 2 dan B3 lalu 3).

c. Analisa Fosfat $\left(\mathrm{PO}_{4}\right)$

Analisa kandungan nitrat dalam air menggunakan metode Hach Programme. Metode pengukuran nitrat dilakukan dengan cara berikut :

1. menyiapkan sampel air pori sedimen sebanyak $10 \mathrm{ml}$;

2. menyiapkan spektrofotometer Hach pada $\mathbf{4 9 0} \mathbf{P}$, kemudian pilih start;

3. Menyiapkan 6 botol sampel; 3 botol ditandai sebagai blanko dan 3 botol lain sebagai sampel (gunakan kertas label untuk pelabelan pada tutup botol sampel); (B1, B2, dan B3 sebagai blanko dan 1,2 dan 3 sebagai sampel);

4. Mengisi botol B1 B2 dan B3 dengan $10 \mathrm{ml}$ air sampel sebagai blanko; botol 12 dan 3 sebagai sampel yang akan ditambah reagen;

5. Menambahkan reagen Phos Ver3 ke dalam botol 123 ;

6. Membolak balikan botol 123 sebanyak dua kali;

7. Mengatur waktu pada spektro selama dua menit serta mendiamkan botol 123 selama dua menit. sambil menuggu keenam botol sampel sebaiknya dibersihkan dengan tisu sehingga tidak ada sidik jari yang menempel;

8. Ketika waktu berbunyi, pilih ikon waktu dan tekan $\mathbf{O K}$;

9. Menyiapkan botol B1 B2 B3 lalu masukkan B1 kedalam spektrofotometer;

10. Kemudian tekan ikon Zero, layar akan menunjukkan $\mathbf{0 , 0 0 ~} \mathbf{~ m g} / \mathbf{L}$;

11. Selanjutnya memasukkan botol 1 kedalam spektro dan lakukan pembacaan; Hasil akan muncul dalam $\mathbf{m g} / \mathbf{L}$;

12. Lakukan hal yang sama pada sampel berikutnya (B2 lalu 2 dan B3 lalu 3).

\section{d. Metode pengukuran kualitas air}

Metode pengukuran kualitas air dilakukan di setiap titik sampling dengan melakukan tiga kali pengulangan di setiap pengukuran. Tahap - tahap pengukuran kualitas air :

1. Pengukuran salinitas dengan menggunakan refraktometer

2. Pengukuran suhu dengan menggunakan termometer

3. Pengukuran $\mathrm{pH}$ dengan menggunakan $\mathrm{pH}$ papper

4. Pengukuran DO dengan menggunakan DO meter diukur pada setiap titik lokasi pengambilan sampel. Penggunakan DO meter dengan cara memasukkan sensor ke dalam perairan kemudian ditunggu sampai skalanya stabil. Pengukuran DO dilakukan pada dasar perairan.

5. Pengkuran kecerahan : pada setiap titik lokasi pengambilan sampel dengan menggunakan Secchi disk. Secchi disk dimasukan ke dalam perairan kemudian dilihat skala dimana Secchi disk masih terlihat jelas (K1) dan skala dimana Secchi disk terlihat remang-remang (K2). Menurut Effendi (2003), persamaan untuk mengukur kecerahan sebagai berikut :

$$
\mathrm{D}=\frac{\mathrm{K} 1+\mathrm{K} 2}{2}
$$

Keterangan:

$\mathrm{D}=$ Kecerahan $(\mathrm{cm})$

$\mathrm{K} 1=$ Secchi disk masih terlihat jelas $(\mathrm{cm})$

$\mathrm{K} 2=$ Secchi disk terlihat remang-remang $(\mathrm{cm})$ 


\section{Hasil dan Pembahasan}

\section{Gambaran umum lokasi penelitian}

Lokasi penelitian berada di perairan Sungai Wedung yang terletak di wilayah Dusun Angin-angin Desa Buko Kecamatan Wedung. Desa Buko memiliki luas wilayah sebesar 658,960 Ha dengan jumlah penduduk \pm 4.918 jiwa dan sebagian besar penduduknya adalah nelayan.

Secara geografis, Desa Buko dibatasi oleh:

1. Sebelah Utara adalah Desa Berahan Wetan dan Desa Bungo

2. Sebelah Selatan adalah Desa Ngawen dan Desa Wedung

3. Sebelah Timur adalah Desa Kenduren dan Desa Rawit

4. Sebelah Barat adalah Desa Mandung dan Desa Berahan Kulon

Lokasi penelitian ini mempunyai kedalaman antara 2 - 3 m. Perairan Sungai Wedung menerima limbah yang berasal dari lalu lintas kapal dan kegiatan rumah tangga yang berada di sekitar Sungai Wedung.

Sekitar perairan Sungai Wedung terdapat berbagai aktivitas manusia. Lalu lintas kapal, pasar, TPI yang berlokasi di pinggir Sungai Wedung. Beberapa diantaranya membuang limbahnya ke perairan baik langsung maupun tidak langsung. Sepanjang sungai sampai muara terdapat banyak sampah (berupa plastik atau kaca) yang terbawa arus dan terkadang menghambat perjalanan para kapal untuk berlayar. Pada tepi kanan dan kiri Sungai Wedung ditumbuhi oleh tanaman air dan mangrove yang cukup subur.

\section{Hasil analisa nitrat dan fosfat air pori sedimen sungai dan muara}

\section{a. Nitrat di sungai dan muara}

Hasil analisa kandungan nitrat sungai dan muara di lokasi penelitian adalah sebagai berikut :

Histogram hasil perhitungan kandungan nitrat sungai dan muara sungai pada waktu pagi dan siang tersaji pada Gambar 1.

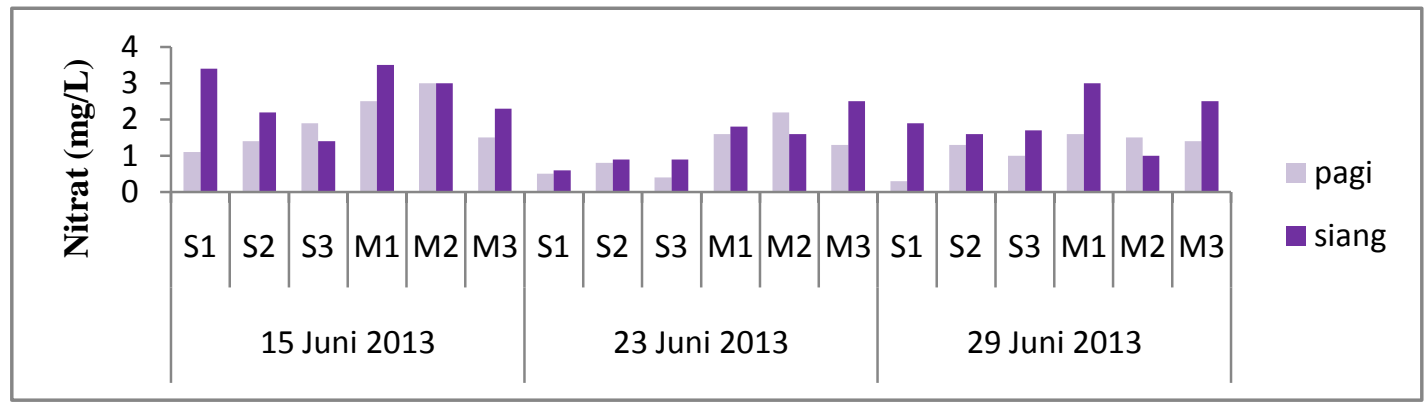

Gambar 1. Kandungan Nitrat Sungai (S) dan Muara (M) pada Waktu Pagi dan Siang

Dari hasil histogram diatas terlihat bahwa kandungan nitrat pada sungai dan muara pagi hari berkisar antara $0,3-3 \mathrm{mg} / \mathrm{L} \pm 0,70333$. Untuk siang hari kandungan nitrat pada kedua perairan berkisar antara $0,6-$ $3,5 \mathrm{mg} / \mathrm{L} \pm 0,875744$. Menurut Susana (2005) normalitas kandungan nitrat dalam perairan pada setiap lapisan adalah masing - masing berkisar dari 0 - $4 \mathrm{mg} / \mathrm{L}$.

Kisaran nitrat tersebut Andarias (1991) dalam Samanna (2006) yang menyebutkan bahwa kisaran nitrat 0,9-3,5 mg/l merupakan konsentrasi optimum untuk pertumbuhan alga. Kandungan nitrat dalam sungai dan muara Wedung dapat dikatakan masih dalam kisaran normal sehingga perairan tersebut cukup subur. Organisme dapat berkembang biak dengan baik. Hal ini didukung pernyataan wetzel (1975) dalam Hidayat (2001) menyatakan bahwa nitrat dapat digunakan untuk menentukan tingkat kesuburan perairan. Tipe perairan oligotrofik memiliki kandungan nitrat sebesar $0-1 \mathrm{mg} / \mathrm{L}$, mesotrofik $1-5 \mathrm{mg} / \mathrm{L}$, dan eutrofik $5-50$ $\mathrm{mg} / \mathrm{L}$.

\section{b. Fosfat di sungai dan muara}

Analisa kandungan fosfat sungai dan muara di lokasi penelitian adalah sebagai berikut:

Histogram perhitungan kandungan fosfat sungai dan muara sungai pada waktu pagi dan siang tersaji pada Gambar 2.

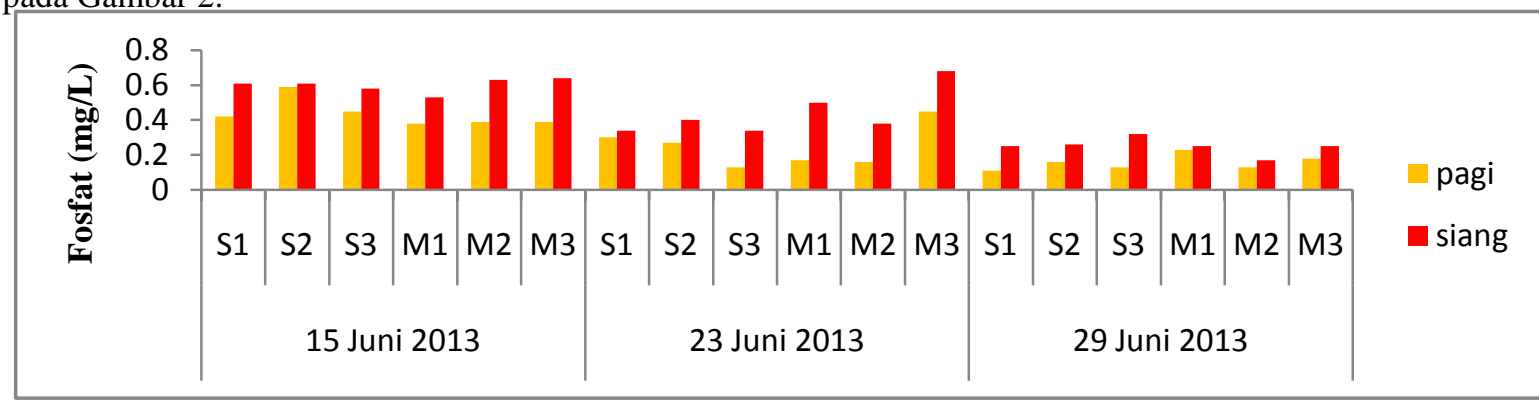

Gambar 2. Kandungan Fosfat Sungai (S) dan Muara (M) pada Waktu Pagi dan Siang 
Dari hasil histogram diatas terlihat bahwa kandungan fosfat pada pagi hari untuk sungai dan muara berkisar $0,11-0,59 \mathrm{mg} / \mathrm{L} \pm 0,145117$. Siang hari kandungan fosfat pada kedua perairan berkisar antara 0,17 $-0,64 \mathrm{mg} / \mathrm{L} \pm 0,167015$. Kandungan fosfat yang cukup tinggi menyebabkan perairan tersebut subur. Organisme perairan dapat berkembang baik di Sungai Wedung. Kandungan fosfor dalam air merupakan karakteristik kesuburan perairan yang bersangkutan. Pada umumnya perairan yang mengandung ortofosfat antara $0,03-0,1 \mathrm{mg} / \mathrm{L}$ adalah perairan yang oligotrofik. Kandungan antara $0,11-0,3 \mathrm{mg} / \mathrm{L}$ perairan yang mesotrofik dan kandungan antara 0,31-1,0 $\mathrm{mg} / \mathrm{L}$ adalah perairan eutrofik (Wetzel, 1975 dalam Hidayat 2001).

Sedimen merupakan tempat penyimpan fosfor yang baik. Tanaman dan hewan yang mati akan diuraikan oleh bakteri pengurai yang selanjutnya akan mengendap di dasar perairan. Menurut Paytan dan McLaughlin (2007) dalam Risamasu dan Prayitno (2011), senyawa fosfor yang terikat di sedimen dapat mengalami dekomposisi dengan bantuan bakteri maupun melalui proses abiotik menghasilkan senyawa fosfor terlarut. Keberadaan fosfor dalam perairan sangat berpengaruh terhadap keseimbangan ekosistem perairan. Tingginya kadar fosfat dapat memicu pertumbuhan tanaman air dan juga alga secara berlebihan. Menurut Boney (1989) dalam Effendi (2003), keberadaan fosfor secara berlebihan disertai dengan keberadaan nitrogen dapat menstimulir ledakan pertumbuhan alga di perairan. Perkins (1974) dalam Silalahi (2010), perairan yang mengandung kadar fosfor tinggi melebihi kebutuhan normal organisme akuatik akan menyebabkan terjadinya eutrofikasi.

\section{Hasil analisa variabel kualitas air} a. Salinitas

Hasil pengukuran salinitas sungai dan muara di lokasi penelitian adalah sebagai berikut:

Tabel 1. Kandungan Salinitas Sungai dan Muara (dalam \%o)

\begin{tabular}{c|ccc}
\hline \multirow{2}{*}{ Tempat } & \multicolumn{3}{c}{ Salinitas } \\
\cline { 2 - 4 } & 15 Juni 2013 & 23 Juni 2013 & 29 Juni 2013 \\
Sungai & 0 & 0 & 0 \\
Muara & 25 & 25 & 24 \\
\hline
\end{tabular}

Dari tabel diatas terlihat bahwa untuk muara kurang lebih 25\%. Mony (2004) menyatakan bahwa salinitas di permukaan perairan muara sungai berkisar antara 15 - 35\%o. Salinitas akan terus meningkat nilainya dari muara ke arah laut. Kisaran tersebut masih cocok untuk muara sehingga mempengaruhi banyaknya kandungan nitrat dan fosfat yang dihasilkan perairan.

Salinitas perairan estuaria dipengaruhi oleh adanya perubahan-perubahan proses fisika dalam perairan seperti penguapan, pengembunan, kandungan air yang berubah, perubahan unsur-unsur pembentuk garam. Unsur-unsur yang bisa berubah dalam air antara lain fosfat dan nitrat karena hal ini erat kaitannya dengan aktifitas biologi, sehingga perubahan salinitas akan mempengaruhi kandungan nitrat dan fosfat (Siagian, 2000).

Wilayah perairan estuaria daerah tropis dikenal tinggi produktivitasnya karena mempunyai kandungan zat hara yang tinggi dalam air pori. Karena terletak di daerah tropis, maka hampir sepanjang tahun perairan Indonesia mempunyai suhu permukaan yang tinggi, berkisar antara $26-30 \mathrm{C}$. Sifat ini umumnya berasosiasi dengan air yang berkadar garam atau bersalinitas rendah, yaitu $\pm 27,33 \mathrm{ppm}$ di lapisan permukaan (Patriquin, 1992).

b. Suhu

Hasil pengukuran suhu perairan di lokasi penelitian adalah sebagai berikut :

Dari tabel diatas dapat dilihat Histogram rata-rata suhu perairan di lokasi penelitian seperti tersaji pada gambar 3.

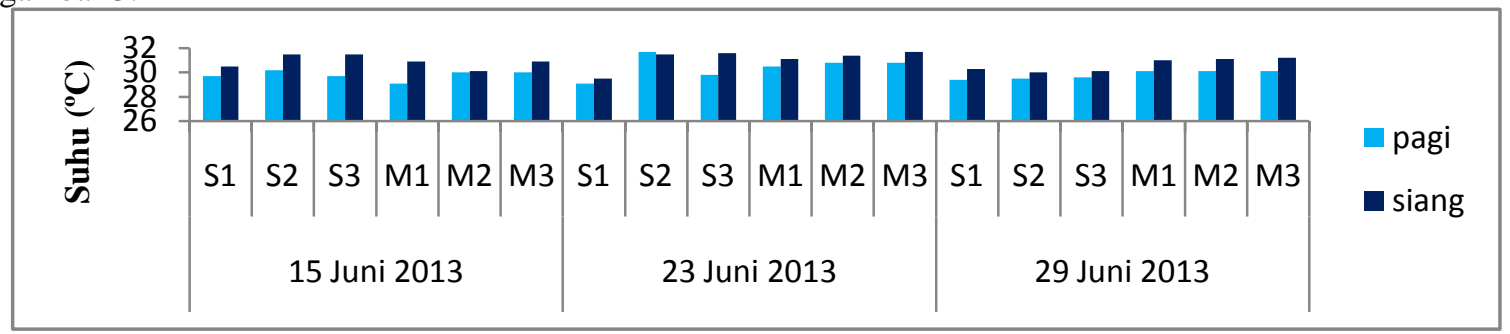

Gambar 3. Kandungan Suhu Perairan pada Pagi dan Siang

Dari hasil histogram diatas terlihat bahwa suhu pada pagi hari untuk sungai dan muara berkisar 29,1 $-32{ }^{\circ} \mathrm{C} \pm 0,646155$. Siang hari kandungan fosfat pada kedua perairan berkisar antara $30-32{ }^{\circ} \mathrm{C} \pm 0,651017$. Gambar 3 menunjukkan nilai suhu perairan pada masing masing minggu pengamatan hampir seragam (variasinya tidak terlalu jauh). Kisaran suhu yang masih terbilang normal tersebut mempengaruhi kandungan nitrat dan fosfat yang dihasilkan sehingga perairan tersebut masih baik digunakan untuk perkembangbiakan organisme. 
Levinton (1982) menyatakan bahwa pengaruh suhu dalam perairan sangat penting dalam hal produktifitas perairan, perairan yang lebih dingin lebih kaya akan nutrient dibandingkan dengan perairan yang lebih hangat. Suhu air laut yang lebih dingin akan meningkatkan penyerapan zat hara untuk mengendap di dasar laut. Sementara saat suhu air laut naik, zat hara akan melarut di air laut karena penurunan laju penyerapan. Kombinasi dari temperatur dan peningkatan kandungan zat hara yang timbul dari pencampuran ini akan meningkatkan produktivitas perairan.

APHA (1989) dalam Hidayat (2001) menyatakan bahwa suhu optimum untuk pertumbuhan fitoplankton dan kehidupan ikan di daerah tropis berkisar antara $25,0-31,0{ }^{\circ} \mathrm{C}$. Meningkatnya suhu di perairan akan meningkatkan toksisitas dari banyak kontaminan - kontaminan terlarut dan akan meningkatkan pula konsumsi oksigen. Suhu juga akan mempengaruhi nitrat dan fosfat dalam perairan, hal ini memungkinkan karena semakin tinggi suhu, semakin rendah kandungan nitrat dan fosfat.

c. $\mathbf{p H}$

Hasil pengukuran $\mathrm{pH}$ perairan di lokasi penelitian adalah sebagai berikut :

Dari tabel diatas dapat dilihat Histogram pH perairan di lokasi penelitian seperti tersaji pada gambar 4.

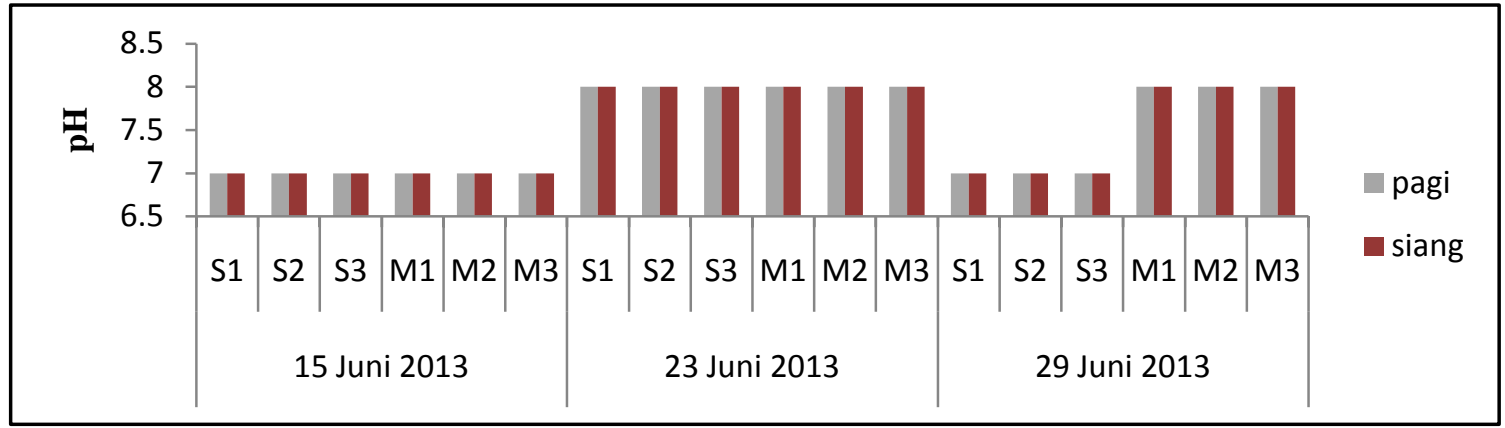

Gambar 4. Nilai pH Perairan di Lokasi Penelitian

Dari histogram diatas terlihat bahwa $\mathrm{pH}$ untuk kedua perairan tersebut sekitar $7-8 \pm 0,514496$. Menurut Santoso (2007) organisme akuatik dapat hidup dalam suatu perairan yang mempunyai nilai $\mathrm{pH}$ yang netral dengan kisaran toleransi antara asam lemah sampai basa lemah. $\mathrm{pH}$ yang ideal bagi kehidupan organisma akuatik pada umumnya berkisar antara 7 sampai 8,5 . Kondisi perairan yang bersifat sangat asam maupun sangat basa membahayakan kelangsungan hidup organisma karena menyebabkan terjadinya gangguan metabolisme dan respirasi. Sementara $\mathrm{pH}$ yang tinggi menyebabkan keseimbangan antara amonium dan amoniak dalam air akan terganggu. Kenaikan $\mathrm{pH}$ di atas netral meningkatkan konsentrasi amoniak yang juga bersifat sangat toksik bagi organisme. Nilai $\mathrm{pH}$ dipengaruhi oleh faktor fisik sedimen, berkaitan dengan konsentrasi bahan-bahan organik yang ada di sedimen. Semakin kecil ukuran butir sedimen, pHnya semakin rendah demikian juga sebaliknya. Perubahan nilai $\mathrm{pH}$ dalam sedimen mempengaruhi sebaran mempengaruhi sebaran mikroorganisme yang metabolismenya tergantung pada sebaran faktor-faktor kimia tersebut. Sebagian mikroorganisme sangat peka terhadap perubahan nilai $\mathrm{pH}$ dalam perairan. Nilai $\mathrm{pH}$ akan mempengaruhi proses-proses biokimia perairan, misalnya proses nitrifikasi akan berakhir jika pH rendah (Effendi,2003).

Nilai $\mathrm{pH}$ untuk Sungai Wedung dirasa sudah cukup optimum karena organisme yang terdapat pada sungai seperti tanaman mangrove juga dapat tumbuh subur. Biota lainnya seperti ikan pada kisaran $\mathrm{pH} 7-8$ dapat berkembangbiak secara baik. Perairan tersebut juga dikatakan subur karena $\mathrm{pH}$ tidak terlalu basa dan tidak terlalu asam. Hal ini sesuai dengan pernyataan Mony (2004) bahwa perairan yang baik untuk fitoplankton adalah $\mathrm{pH}$ normal, yaitu 7,0. Perairan dengan $\mathrm{pH} 4-5$ termasuk tipe perairan oligotrofik, $\mathrm{pH} 5$ 7 termasuk tipe mesotrofik dan $\mathrm{pH} 7-9$ termasuk tipe perairan eutrofik. Penggolongan tersebut tidak termasuk untuk perairan budidaya ikan.

\section{d. Oksigen terlarut}

Hasil rata-rata pengukuran oksigen terlarut perairan di lokasi penelitian adalah sebagai berikut.

Dari tabel diatas dapat dilihat Histogram oksigen terlarut perairan di lokasi penelitian seperti tersaji pada gambar 5 .

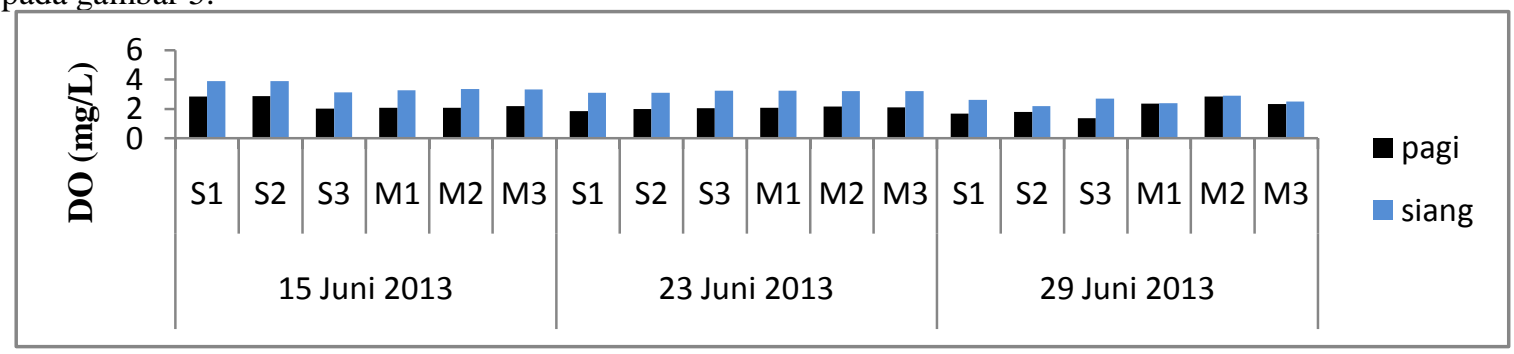

Gambar 5. Kandungan oksigen terlarut Perairan di Lokasi Penelitian 
Dari hasil histogram diatas terlihat bahwa kandungan oksigen terlarut pada pagi hari untuk sungai dan muara berkisar antara $1,37-2,86 \mathrm{mg} / \mathrm{L} \pm 0,392698$. Untuk siang hari kandungan oksigen terlarut berkisar 2,2 $-3,9 \mathrm{mg} / \mathrm{L} \pm 0,4575$. Pada umumnya kandungan oksigen sebesar 5,0 ppm dengan suhu air berkisar antara $20,0-30,0{ }^{\circ} \mathrm{C}$ relatif masih baik untuk kehidupan ikan-ikan, bahkan apabila dalam perairan tidak terdapat senyawa-senyawa yang bersifat toksik (tidak tercemar) kandungan oksigen sebesar 2,0 ppm sudah cukup untuk mendukung kehidupan organisme perairan (Marabessy et al., 2005). Dari pernyataan diatas dapat disimpulkan bahwa kandungan oksigen terlarut di Sungai Wedung masih cocok untuk organisme yang terdapat di perairan dan mempengaruhi tingkat kesuburan perairan tersebut.

\section{e. Kecerahan}

Hasil rata-rata pengukuran kecerahan perairan di lokasi penelitian adalah sebagai berikut.

Dari tabel diatas dapat dilihat Histogram kecerahan perairan di lokasi penelitian seperti tersaji pada gambar 6.

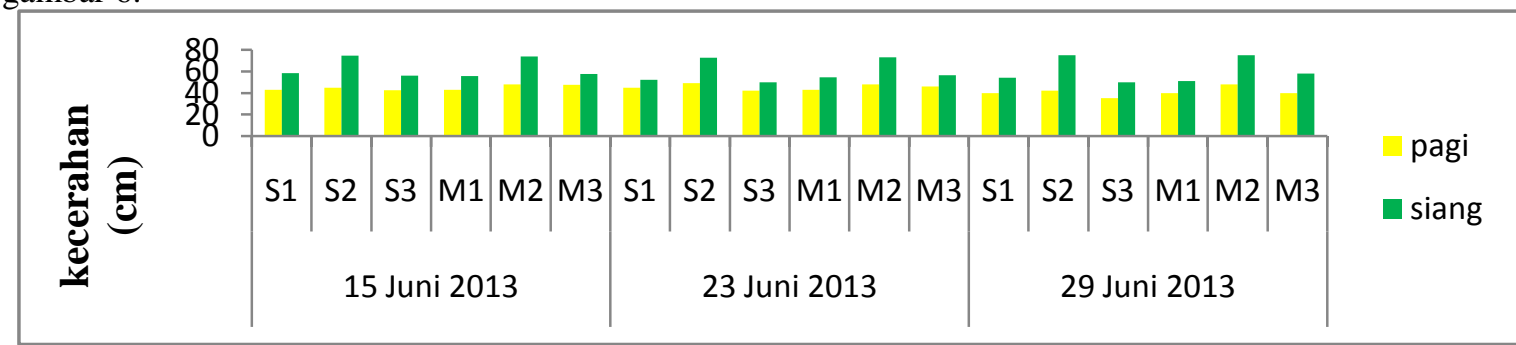

Gambar 6. Histogram Kecerahan Perairan di Lokasi Penelitian

Dari hasil histogram diatas terlihat bahwa kecerahan sungai dan muara pada pagi dan siang hari berkisar antara $35-49 \mathrm{~cm} \pm 3,695077$. Untuk siang hari kecerahan pada kedua perairan berkisar antara $50-$ $75 \mathrm{~cm} \pm 9,812166$. Perairan yang memiliki sedimentasi tinggi dapat membahayakan kehidupan di lingkungan perairan, diantaranya sedimen yang menyebabkan kekeruhan air dengan menghalangi penetrasi cahaya yang masuk ke dalam air sehingga dapat mengganggu kehidupan organisme didalamnya (Dahuri et al., 2001).

Dilihat dari tingkat kecerahan perairan tersebut masih tergolong perairan yang subur karena sedimen yang mengendap tidak terlalu banyak. Sehingga tidak menimbulkan kekeruhan yang parah. Tebal tipisnya daerah fotosintesis di perairan merupakan proses penting bagi organisme produsen di perairan. Hal ini sesuai dengan pernyataan Hidayat (2001) tipe perairan oligotrofik mempunyai tingkat kecerahan > 6 meter, mesotrofik 3- 6 meter dan eutrofik $<3$ meter.

\section{Pembahasan}

Sungai Wedung merupakan sungai yang memiliki arti penting bagi masyarakat sekitar. Sungai tersebut digunakan untuk warga sekitar sebagai sarana untuk menangkap ikan. Sungai Wedung dilihat dari status kesuburan perairan termasuk eutrofik. Perairan eutrofik adalah perairan yang memiliki kadar hara dan kandungan bahan organik tinggi.

Bahan-bahan organik dan zat hara dari sungai yang masuk secara massive ke perairan pesisir berperan penting dalam menstimulasi proses biologi di perairan tersebut. Sebagai contoh, proses pengkayaan zat hara yang berasal dari upwelling, sumber antropogenik dan masukan air sungai mneyebabkan peningkatan pertumbuhan fitoplankton di lingkungan pesisir. Zat hara yang umum menjadi fokus perhatian di lingkungan perairan adalah fosfor dan nitrogen. Kedua unsur ini memiliki peran vital bagi pertumbuhan fitoplankton atau alga yang biasa digunakan sebagai indikator kualitas air dan tingkat kesuburan suatu perairan. Di dalam alga, perbandingan nitrogen dan fosfor mendekati rasio Redfield sebesar 16:1 (basis atom) atau 7,5:1 (basis massa) (Risamasu dan Prayitno, 2011).

Kandungan nitrat di Sungai Wedung pada pagi hari berkisar antara $0,3-3 \mathrm{mg} / \mathrm{L}$ dan pada siang hari $0,6-3,5 \mathrm{mg} / \mathrm{L}$. Dilihat dari Histogramkandungan nitrat secara keseluruhan mengalami kenaikan. Menurut Simanjuntak dkk (2012) algae khususnya fitoplankton akan dapat tumbuh normal pada kisaran nitrat 0,9 $3,5 \mathrm{mg} / \mathrm{L}$. Dari hasil yang didapatkan bahwa nilai tertinggi kandungan nitrat terdapat pada muara. Hal ini sesuai dengan pendapat Muchtar (1996) bahwa kandungan nitrat yang tinggi pada umumnya di daerah sekitar muara sungai dan semakin rendah ke arah laut lepas, begitu juga pada lapisan $10 \mathrm{~m}$, distribusi horisontal kandungan nitrat perairan ini semakin menurun semakin kearah laut lepas.

Fosfat yang terkandung dalam Sungai Wedung berkisar antara $0,11-0,59 \mathrm{mg} / \mathrm{L}$ pada pagi hari. Siang hari kandungan fosfat di perairan tersebut meningkat menjadi $0,17-0,68 \mathrm{mg} / \mathrm{L}$. Berdasarkan penelitian yang dilakukan oleh Abentin et al (2000) kandungan fosfat di dasar perairan berkisar antara 0,05-1,5 mg/L. Kadar fosfat tersebut masuk dalam kategori cukup pekat. Seperti halnya pada nitrat, tingginya kandungan fosfat di dasar perairan karena dasar perairan umumnya kaya akan zat hara, baik yang berasal dari dekomposisi sedimen maupun senyawa-senyawa organik yang berasal dari jasad flora dan fauna yang mati.

Kandungan unsur hara pada air sangat dipengaruhi oleh parameter fisika kimia seperti suhu, pH, salinitas, oksigen terlarut dan kecerahan. Unsur hara yang tersedia pada air memiliki sifat yang dinamis 
karena dapat berubah bentuk secara kimiawi. Proses kimiawi ini sangat dipengaruhi oleh nilai dari parameter fisika-kimia air tersebut (Sammana, 2006).

Kadar oksigen terlarut pada perairan Wedung berdasarkan hasil penelitian berkisar antara 1,37-3,9 $\mathrm{mg} / \mathrm{L}$. Kisaran tersebut menunjukkan bahawa kandungan oksigen terlarut di sungai tersebut dibawah batas optimum. Pada umumnya kandungan oksigen sebesar 5,0 ppm dengan suhu air berkisar antara $20,0-30,0{ }^{\circ} \mathrm{C}$ relatif masih baik untuk kehidupan ikan-ikan, bahkan apabila dalam perairan tidak terdapat senyawa-senyawa yang bersifat toksik (tidak tercemar) kandungan oksigen sebesar 2,0 ppm sudah cukup untuk mendukung kehidupan organisme perairan (Marabessy et al., 2005).

Rendahnya kandungan oksigen terlarut mungkin disebabkan oleh cuaca. Karena pada hasil penelitian yang didapat oksigen terendah terjadi pada pengulangan ketiga. Pada saat itu cuaca mendung sehingga cahaya matahari yang masuk kedalam perairan hanya sedikit. Pengaruhnya terhadap kandungan nitrat dan fosfat pada pengulangan ketiga yang cenderung menurun. Suhu yang optimum membuat proses nitrifikasi berjalan secara baik. Hal ini sesuai dengan pendapat Sammana (2006) bahwa Aspek penting dari distribusi oksigen terlarut di perairan yaitu berhubungan dengan parameter kimia lainnya seperti fosfat, nitrat, karbondioksida, dan $\mathrm{pH}$. Dalam hal ini oksigen berperan pada proses kimiawi dalam pembentukan parameter parameter kimia tersebut. Kisaran suhu $20-25^{\circ} \mathrm{C}$ proses nitrifikasi berjalan secara optimum.

Suhu pada perairan selama tiga kali pengulangan berkisar antara $29,1-32{ }^{\circ} \mathrm{C}$. Suhu tersebut masih cocok untuk kehidupan organisme di perairan. Pada siang hari suhu perairan bisa mencapai $32^{\circ} \mathrm{C}$. Pengukuran suhu pada siang hari dilakukan pada pukul 12.30. Hal ini sesuai dengan penelitian Nurhayati dan Suyarso (2008) nilai minimum suhu air 29,275 "C pada penelitian bulan Februari 2007, pada saat cuaca dalam kondisi hujan gerimis dan mendung. Suhu air maksimum 31,223 "C dijumpai pada lapisan permukaan dan terjadi kirakira pukul 12.30 waktu setempat, dimana pancaran radiasi matahari sangat tajam ke perairan serta dalam kondisi yang sedang pasang.

Biasanya salinitas berkaitan dengan suhu dalam mempengaruhi kehidupan organisme perairan. Peningkatan suhu akan diikuti oleh peningkatan salinitas karena evaporasi meningkat. Pada pengulangan pertama dan kedua mendapatkan salinitas sebesar $25 \%$. Sedangkan pada pengulangan ketiga salinitas menurun menjadi $24 \%$. Hal ini disebabkan tempat penelitian habis diguyur hujan. Menurut Nurhayati dan Suyarso (2008) menyatakan bahwa salinitas rendah menjadi suatu indikasi pengaruh sungai setempat dan curah hujan memberikan kontribusi yang nyata pada perairan muara sungai dan pantai.

Kandungan $\mathrm{pH}$ selama tiga kali pengulangan berkisar antara $7-8$. Kandungan $\mathrm{pH}$ tersebut relatif tidak fluktuasi. Kisaran tersebut mendukung jalannya proses nitrifikasi. Effendi (2003) menyatakan bahwa pada $\mathrm{pH}$ kurang dari 6 (asam) reaksi pada proses nitrifikasi berhenti. Selain itu kestabilan nilai pH juga berpangaruh terhadap proses hidrolisis pembentukan ortofosfat pada air.

Tingkat kecerahan Sungai Wedung berkisar antara $40-75 \mathrm{~cm}$. Kecerahan yang didapatkan sesuai dengan kedalaman atau topografi ekosistem. Untuk titik sampling kedua sungai atau pun muara kecarahan berkisar antara $72,5-75 \mathrm{~cm}$ karena kedalaman pada titik tersebut hampir mencapai 3 meter. Menurut Asmawi (1983) dalam Suparjo (2009), nilai kecerahan yang baik untuk kehidupan organisme adalah lebih besar dari $0,45 \mathrm{~m}$ sehingga penetrasi dan absorbsi di perairan tersebut akan berlangsung optimal.

Hasil analisa data menggunakan uji $\mathrm{T}$ Independen atau Independent T-Test adalah untuk nitrat $\mathrm{P}=$ 0,787 dan untuk fosfat $\mathrm{P}=0,640$. Yang berarti 0,787 dan $0,640>0,05$ variasi data tersebut sama atau homogen. Hasil analisa data untuk kandungan nitrat sebesar 0,002. Nilai tersebut lebih kecil dari 0,05 yang berarti dapat ditarik kesimpulan bahwa terdapat perbedaan kandungan nitrat dalam air pori sedimen sungai dan muara Sungai Wedung. Faktor lingkungan yang mempengaruhi kandungan nitrat adalah oksigen terlarut. Nilai P untuk oksigen terlarut adalah 0,018. Menurut hasil analisis regresi linear pengaruh oksigen terlarut terhadap kandungan nitrat sebesar $15,4 \%$ dan $84,6 \%$ sisanya berasal dari pengaruh faktor faktor lain.

Hasil analisis data untuk kandungan fosfat sebesar 0,820 . Nilai tersebut lebih besar daripada 0,05 sehingga dapat ditarik kesimpulan bahwa tidak terdapat perbedaan pada kandungan fosfat dalam air pori sedimen sungai dan muara Sungai Wedung. Faktor lingkungan yang mempengaruhi kandungan fosfat adalah oksigen terlarut, suhu, $\mathrm{pH}$, dan kecerahan. Masing masing memiliki nilai $\mathrm{P}$ kurang dari 0,05 . Pengaruh oksigen terlarut pada kandungan fosfat sebesar $48,7 \%$, suhu $12,5 \%, \mathrm{pH} 12,1 \%$ dan kecerahan $15,5 \%$. Sisa $11,2 \%$ berasal dari faktor lain.

Kandungan nitrat sungai lebih kecil daripada di muara. Akan tetapi kandungan zat tersebut masih dalam batas normal untuk perairan sehingga masih cocok atau aman untuk digunakan sebagai tempat untuk organisme air. Untuk kandungan nitrat di muara dirasa cukup tinggi karena melihat dari ekosistem muara yang cukup baik untuk organisme. Fosfat pada perairan sungai dan muara tidak terdapat perbedaan karena fosfat pada perairan kandungannya lebih stabil dibanding nitrat karena fosfat mengendap dan fosfat memerlukan waktu yang lama untuk terurai.

Dari hasil penelitian yang dilakukan dapat diambil kesimpulan bahwa perairan tersebut masih dalam kategori baik atau cukup subur sehingga pelu kepedulian masyarakat sekitar untuk menjaga perairan tersebut. Kondisi demikian ditunjukkan dengan nilai kandungan unsur hara pada semua perlakuan berada pada kisaran yang optimum. 


\section{Kesimpulan}

Kesimpulan yang didapat dari penelitian ini antara lain :

1. Terdapat perbedaan kandungan unsur hara khususnya nitrat dalam air pori sedimen di sungai dan muara. Dalam hal ini muara lebih tinggi kandungannya. Untuk fosfat tidak terdapat perbedaan.; dan

2. Faktor-faktor yang berperan dalam perbedaan kandungan nitrat adalah oksigen terlarut dan untuk kandungan fosfat dalam air pori sedimen adalah suhu, oksigen terlarut, dan kecerahan.

\section{Ucapan Terima Kasih}

Ucapan terima kasih ditujukan kepada Bapak Sugeng (Teknisi Jurusan Teknik Sipil) yang telah membantu di lapangan dan bersedia membuatkan pore water pressure dan penyedot air kolom. Ucapan terima kasih ditujukan pula kepada Dr. Ir. Djoko Suprapto, M.Sc dan Dr. Ir. Max Rudolf Muskananfola, M.Sc atas bimbingannya dalam penyusunan skripsi ini.

\section{Daftar Pustaka}

Dahuri, R.J. Rais, S.P. Ginting, dan M.J. Sitepu. 1996. Pengelolaan Wilayah Pesisir dan Lautan Secara Terpadu. PT. Pradnya Paramita, Jakarta.Effendi, H. 2003. Telaah Kualitas Air Bagi Pengelolaan Sumberdaya dan Lingkungan Perairan. Kanisius. Yogyakarta.

Hadi, S. 1993. Metodologi research.Penulisan papper, skripsi, thesis, dan disertasi. Yayasan penerbit Fakultas Psikologi UGM. Yogyakarta.

Harsono. 2002. Analisis Tingkat Pencemaran Air Sungai di Daerah Estuari Jawa Tengah. Badan Penelitian dan Pengembangan Propinsi Jawa Tengah.

Hidayat, Y. 2001. Tingkat Kesuburan Perairan Berdasarkan Kandungan Unsur Hara N dan P Serta Struktur Komunitas Fitoplankton di Situ Tonjong, Bojonggede, Kabupaten Bogor, Jawa Barat. [Skripsi]. Program Studi Manajemen Sumberdaya Perairan. Fakultas Perikanan dan Ilmu Kelautan. Institut Pertanian Bogor.

Hutagalung, H. dan A. Rozak. 1997. Metode Analisis Air Laut, Sedimen dan Biota. Buku Kedua. Puslitbang Oseanologi-LIPI. Jakarta.

Levinton, J.F. 1982. Marine Ecology. New Jersey Prentice-Hall Inc. Englewood Cliff.

Marasabessy, M.D. Edward, T. Kai-supy. 2005. Kadar Oksigen Terlarut di Ekosistem Terumbu Karang Kep. Mentawai, Nias, dan Sibolga untuk Kepentingan Biota Laut dan Pariwisata, Prosiding: Seminar Nasional Perikanan STIP. Jakarta.

Mony. 2004. Analisis Kondisi Lingkungan Perairan Muara Sungai Cimandiri Teluk Pelabuhan Ratu Sukabumi Jawa Barat. [Skripsi]. Ilmu Kelautan. Fakultas Perikanan dan Ilmu Kelautan. Institut Pertanian Bogor.

Nurhayati dan Suyarso. 2008. Gambaran Oseanografi dan Variabilitas Lingkungan di Perairan Cirebon, Jawa Barat. Oseanologi dan Limnologi di Indonesia.

Nybakken, W.J. 1988. Biologi Laut : Suatu Pendekatan Ekologi. P.T. Gramedia, Jakarta

Patriquin, D. G. 1972. The origin of nitrogen and phosphorus for growth of marine angiospermae Thlassia testudinum. Mar. Biol., 15:35 - 46.

Risamasu, F.J.L dan H.B. Prayitno. 2011. Kajian Zat Hara Fosfat, Nitrit, Nitrat dan Silikat di Perairan Kepulauan Matasiri, Kalimantan Selatan. Ilmu Kelautan.

Sammana, I.A. 2006. Keberadaan Unsur Hara Dalam Media Air Laut Bersubstrat Zeocrete Pada Tingkat Konsentrasi Berbeda. [Skripsi]. Manajemen Sumberdaya Perairan. Fakultas Perikanan Dan Ilmu Kelautan. Institut Pertanian Bogor. Bogor.

Santoso, A. D. 2007. Kandungan Zat Hara Fosfat pada Musim Barat dan Musim Timur di Teluk Hurun Lampung. Jurnal Teknologi Lingkungan. Jakarta.

Sastrawijaya, T. 1991. "Pencemaran Lingkungan". PT Rineka Cipta, Jakarta.

Siagian, M. 2000. Diktat Ekologi Perairan. Universitas Riau Press, Pekanbaru.

Suparjo, M.N. 2009. Kondisi Pencemaran Perairan Sungai Babon Semarang. Manajemen Sumberdaya Peariran. Perikanan. Universitas Diponegoro. Semarang.

Wibisono, M. S. 2005. Pengantar Ilmu Kelautan. PT Gramedia. Jakarta. 